\title{
FELGYORSÍTOTT EVOLÚCIÓ - A 2018-AS KÉMIAI NOBEL-DÍJ
}

\section{SPEED EVOLUTION - THE NOBEL PRIZE IN CHEMISTRY 2018}

\author{
Beke-Somfai Tamás \\ PhD, tudományos főmunkatárs, csoportvezető \\ MTA Természettudományi Kutatóközpont Anyag- és Környezetkémiai Intézet \\ beke-somfai.tamas@ttk.mta.hu
}

\section{ÖSSZEFOGLALÁS}

\begin{abstract}
A 2018-as kémiai Nobel-díjat három kutatónak ítélték oda: a díj egyik felét Frances Arnold kapta „enzimek irányított evolúciójáért", míg a másik felét Sir Gregory P. Winter és George P. Smith érdemelte ki „peptidek és antitestek fágbemutatásáért”. Az irányított evolúció módszerével a fehérjemérnökség olyan fázisba érkezett, ahol már az élőlényekben nem használt reakciókat is képesek kifejlesztett fehérjék katalizálni, míg a fágbemutatás forradalmasította a gyógyszeripari fejlesztéseket és új, antitestalapú gyógyszermolekulák alkalmazásához vezetett.
\end{abstract}

\section{ABSTRACT}

The 2018 Nobel Prize in Chemistry was awarded for three scientists, one half of the prize 'for the directed evolution of enzymes' to Frances Arnold, whereas the other half to Sir Gregory P. Winter and George P. Smith, 'for the phage display of peptides and antibodies'. Directed evolution leads to protein engineering and development of new enzymes capable of performing reactions which have not been available for biomolecules, while phage display revolutionized pharmaceutical developments and led to the use of antibodies as drug molecules.

Kulcsszavak: fágbemutatás, irányított evolúció, antitest, enzim, fehérjemérnökség

Keywords: phage display, directed evolution, antibody, enzyme, protein engineering

Az evolúció egészen Charles Darwin első idevágó munkája óta központi szerepet tölt be az élettudományok terén, ugyanakkor - emberöltőn túl mérhető hatásai miatt - mindmáig aktív viták tárgya nem tudományos körökben. Az evolúció igazi erejét az élet változatos körülmények közötti megjelenésén láthatjuk igazán. Egészen forró vizü kutaktól a napsugárzás által nem érintett, magas nyomású tengermélyeken át, száraz sivatagokban, de akár még vákuumban is találhatunk élő organizmusokat. Noha ez elsőre biológiai irányú megfigyelés, mégis szorosan 
füződik a kémia területéhez is, hiszen az élet ilyen extrém skálán történt elterjedéséhez az evolúciónak számos molekuláris szintü, „kémiai problémát” kellett megoldania. Az újabb és újabb körülményekhez való alkalmazkodás során folyamatosan új kémiai reakciók, kémiai problémamegoldások váltak szükségessé, amelyekre sokszor új reakciókat elősegítő enzimek - a fehérjék reakciókat segítő alcsoportjának - kialakulása volt a megfelelö válasz. Az enzimek és más fehérjék számos reakciót vagy molekuláris szintủ folyamatot tesznek lehetővé biológiai környezetben, így „az élet kémiai eszköztáraként” is tekinthetünk rájuk.

A 2018-as kémiai Nobel-díjat éppen ezen jelenség megragadásáért és kontrollált kihasználásért ítélték oda Frances H. Arnold (1/2) amerikai, George P. Smith (1/4) amerikai és Sir Gregory P. Winter (1/4) brit tudósoknak. Munkájukkal fehérjék felgyorsított, mesterségesen irányított evolúcióját sikerült az emberiség segítésére, életminőségünk javítására munkába állítani. Sikerült áttörést vagy (r)evolúciót elérniük a kémia több területén, alapvetően új irányt adva például az antitestalapú gyógyszerfejlesztésnek és az enzimek mérnöki tervezésének.

Az irányított evolúció alkalmazásával Frances Arnold csoportja korábbi felfedezései alapján ma már olyan enzimeket is képes elóállítani, amelyek a ma ismert élőlényekben elő nem forduló kémiai reakciók végbemenetelét segítik elö (katalizálják). Egy konkrét példa a viszonylag drága szervetlen kémiai anyagokat igénylő szén-szilícium kovalens kötés kialakítása. Nincs a természetben olyan enzim, amely ilyen kötést képes lenne kialakítani - nagy valószínűséggel nem volt soha szükség rá az elmúlt 3,7 milliárd év alatt, hiszen a biológiai építőkövek rendszerében nincs olyan részlet, amihez ez a kötés szükséges lenne. Az irányított evolúciót ebben az esetben egy eredetileg elektronszállításért felelős enzimen - a citokróm $C$ nevű fehérjén - hajtották végre egy meghatározott cél felé, sorozatos mutációt gerjesztve a fehérjét termelő sejtekben. Ezután a kedvező mutációkat tartalmazó vonalat kiválasztva azokon ismételt véletlen mutációkat idéztek elö, ezt a folyamatot ismételve, amíg a lépésenként változó enzim végeredményül az iparban jelenleg használatos megoldásoknál egy nagyságrenddel hatékonyabban alakította ki a kívánt kötést. A példa alapján talán már nem is meglepő, hogy Arnold professzor eredeti, 1993-as kísérlete óta a módszer széles körben elterjedt, számos alkalmazása létezik az anyagkémiától a bioüzemanyagokon át orvosbiológiai területekig.

A díj másik fele szintén kémiai problémát oldott meg, biológiai környezetben. George Smith esetében a végső felfedezés inkább a szokott kutatási módon történt: egy új irány keresésének reményében véletlenül egy másik, nem várt terület felfedezéséhez vezetve. Az 1980-as években Smith professzor bakteriofágokkal kezdett el foglalkozni - a bakteriofágok olyan vírusok, amelyek baktériumokat fertőznek meg - annak reményében, hogy gének másolására, génklónozásra tudná azokat hasznosítani. Ekkor már közismert volt, hogy a DNS-ben kódolt módon állítja elő a szervezet a kívánt fehérjéket, de az egyes fehérjékhez tartozó gének 
azonosítása még nem volt rutinszerü. Tekintettel arra, hogy a DNS-technológia még gyerekcipőben járt, ezen kapcsolatok felderítése olybá tűnt, mint tüt keresni a szénakazalban.

Ekkoriban jutott Smith egy - egyszerüségében zseniális - módszer elméleti felvetéséhez, majd bizonyításához. A bakteriofágok viszonylag egyszerü felépítésủek, örökítőanyaguk egy fehérjékből álló kapszulába (ún. kapszidba) van bezárva. A kapszid viszonylag kevés fehérjéből épül fel, és az ezekhez tartozó génrészletek ismertek voltak. Smith ötlete az volt, hogy ha a kapszulán lévő fehérjék génjéhez egy ismeretlen gént kapcsol hozzá, akkor a módosított génü bakteriofág következő generációjában olyan új egyedek képződnek, amelyek kapszulájának felületén az ismeretlen gén által kódolt fehérje is megjelenik majd. Ezzel, mint lentebb látni fogjuk, tulajdonképpen kicserélte a kazalban az egyes szénaszálakat olyanokra, amelyek adott esetben mágneses acéltüként is viselkedhetnek.

Ez időben hatalmas génkönyvtárak álltak rendelkezésre ismeretlen génrészletekkel, amelyekről még nem tudták, hogy melyik fehérjékhez tartozhatnak. Azt viszont tudták, hogy az ún. antitestek nagy hatékonysággal képesek fehérjék azonosítására. Az antitestek maguk is fehérjék, arra specializálódva, hogy bizonyos fehérjékkel egyedi és erős kötést létesítsenek, így szervezetidegen anyagokat ismernek fel, és védekező folyamatokat, immunválaszt indíthatnak el például bakteriális fertőzés esetén. George Smith végül elóállított egy „bakteriofáglevest”, amelyben különféle ismeretlen génrészleteket tartalmazó bakteriofágok voltak, majd olyan antitesteket vetett be, amelyekröl tudott volt, hogy milyen fehérjét kötnek. Így, amikor egy adott fehérje az antitesthez kötődött, a hozzá kapcsolható - eddig ismeretlen - génrészlet is azonosíthatóvá vált.

Leegyszerüsítve ezt a speciális antitest-fehérje kölcsönhatást, az antitest egy olyan speciális mágnes szerepét játssza, amelyben egy adott szénaszál - és általában csak ez az egy szénaszál - tüként viselkedik. Smith pedig az addig számos bakteriofágot tartalmazó oldatból (a kazalból) a mágnessel megtalálta a tüt. Az elméletről végül 1985-ben demonstrálta egy általa jegyzett közleményben, hogy tényleg müködik, és a módszerrel ismert fehérjék ismeretlen génjeinek szekvenciáját (információtartalmát) tudta meghatározni.

Végül azonban ez az eredeti ötlet nem a génklónozásban terjedt széles körben el, ehelyett Gregory Winter és néhány további kutató kezdte el alkalmazni a módszert az 1990-es években arra, hogy új biomolekulákat fejlesszen ki, méghozzá a fenti példához képest némileg fordítva és az irányított evolúcióval kombinálva. Mint fentebb már említettük, az antitestek nagy hatékonysággal képesek célfehérjékhez kötődni. A legtöbb antitest Y alakú, és Winter az Y tetején található kötő régiókat helyezte a bakteriofág génjébe a George Smith által kifejlesztett módon. Így olyan bakteriofágokat kapott, amelyek kapszulájának felszínén az antitestek kötő régiója jelent meg. Kísérletében egy olyan antitestet használt, amelyik egy phOx nevű kismolekulát kötött. Demonstrálta, hogy ha a phOx-et használja arra, 
hogy kiszürje az antitestet tartalmazó bakteriofágot, az ugyanúgy müködik, mint amikor az antitesttel szürte ki George Smith a fehérjét tartalmazó fágkapszulát. Ezt Winter végül arra használta, hogy betegségek kulcsfehérjéit célozza meg, azokat minél jobban kötő antitestekkel. A kezdetben kötődő antitesteken pedig az irányított evolúció segítségével véletlen mutációkat vezetett be, és minden generációból megtartotta azokat a mutációkat, amelyek jobb kötődést mutattak, három generáción át ismételve mindezt. Ezt a technikát alkalmazva az 1990-es években a frissen alapított cégében kifejlesztette az első antitestalapú - adalimumabnak elnevezett - gyógyszeralapanyagot. Ebben a gyógyszerben a hatóanyag egy antitest, amely a fenti irányított evolúciós fejlesztésnek köszönhetően nagyon specifikusan köt, és ezáltal „kivon a forgalomból” egy TNF-alfa nevü fehérjét, mely számos autoimmun megbetegedésben a gyulladás elindításáért felelős. Az adalimumab ezzel tulajdonképpen nagymértékben lassítja a nem kívánt gyulladásos folyamatokat, hiszen az azokat indító fehérjét semlegesíti a szervezetben. A gyógyszert 2002-ben engedélyezték reumás artritisz elleni használatra.

A fentebb leírt módszereket jelentős biológiai háttérrel fejlesztették ki, de a kölcsönhatások kémiai alapja, valamint a bioüzemanyag, a gyógyszeripar, a zöldebb vegyipari irányok és új bioanyagok előállítása terén tett hatalmas elörelépések miatt kémiai jelentőségük globális. Távolabbról megítélve, a 2018-as kémiai díj klasszikusan jó Nobel-díj: az innováció zsenialitása a módszerek egyszerüségéből ered, azonban a probléma feltevéséhez, majd a kutatás során elért felfedezéshez - a biztos kémiai háttér mellett - interdiszciplináris látásmód is szükséges volt. 